\title{
POWTÓRNE WYKORZYSTYWANIE ŚWIĄTYŃ POGAŃSKICH W PÓŹNEJ STAROŻYTNOŚCI (na przykladzie prowincji wschodnich)
}

Pośród wielu zjawisk, jakie zdominowały późną starożytność, na szczególną uwagę zasługuje chrystianizacja Imperium Rzymskiego. Jednym z jej elementów była walka z ostoją pogaństwa - świątyniami ${ }^{1}$. Celem tego artykułu nie jest jednak przedstawienie zjawiska destrukcji świątyń pogańskich w późnej starożytności, lecz omówienie sposobów ich powtórnego wykorzystywania. W niniejszym artykule zestawimy przede wszystkim relacje pochodzące ze źródeł pisanych, które tylko częściowo poparte zostaną wynikami badań archeologicznych.

1. Uwagi wstępne. Wystąpienie państwa przeciw świątyniom pogańskim było jednym ze skutków zmiany polityki religijnej Imperium Rzymskiego, kiedy państwo począwszy od Konstantyna Wielkiego zaczęło realizować politykę prochrześcijańską. Czy jednak owa zmiana w polityce religijnej musiała doprowadzić do wystąpienia państwa przeciw świątyniom? Musiała, po pierwsze dlatego, iż antyczne chrześcijaństwo nie dopuszczało możliwości współistnienia $\mathrm{z}$ jakąkolwiek religią, a po drugie świątynie będące ostoją kultów pogańskich były przysłowiową solą w oku wielu współczesnych dostojników kościelnych, którzy w dużym stopniu byli animatorami nowej polityki religijnej państwa w IV i V wieku.

Jaka była podstawa prawna występowania zarówno państwa, jak i poszczególnych grup chrześcijan, przeciwko świątyniom? Poza najczęściej bezprawnymi atakami fanatycznych chrześcijan, często zachęcanych do tego przez swych

${ }^{1}$ Na ten temat por. m.in.: F. Trombley, Hellenic Religion and Christianization c. 370-529, vol. I-II, Leiden - New York - Köln 1993-1994; E. von Lasaulx, Der Untergang des Hellenismus und die Einziehung seiner Tempelgüter durch die christlichen Kaiser, München 1854; D. Metzler, Ökonomische Aspekte des Religionswandels in der Spätantike: die Enteignung der heidnischen Tempel seit Konstantin, „Hephaistos” 3(1981) 27-40; G. Fowden, Bishops and Temples in the Eastern Roman Empire A. D. 320-435, JT 29(1978) 53-78; W. H. C. Frend, Monks and the End of Greco-Roman Paganism in Syria and Egypt, „Cristianesimo nella Storia” 11(1990) 469-484; R. Klein, Spätantike Tempelzerstörungen im Widerspruch christlicher Urteile, „Studia Patristica” 24(1993) 135-142. 
pasterzy $^{2}$, akcje przeciw świątyniom pogańskim podejmowane były na skutek rozporządzeń wydawanych przez poszczególnych władców. Do kogo jednak w interesującym nas okresie „należały” świątynie i ich majątki? Libaniusz wygłaszając mowę w obronie świątyń w końcu lat osiemdziesiątych IV wieku, utrzymywał, iż „świątynie są własnością panującego"3. Odpowiedź na wyżej postawione pytanie jest mimo wszystko złożona. Według A.H.M. Jonesa, wiele świątyń znajdowało się pod bezpośrednim zarządem miast, dlatego też wydawane od Konstantyna Wielkiego rozporządzenia nakazujące konfiskatę majątku świątynnego negatywnie odbijały się na ich kondycji ekonomicznej ${ }^{4}$. Majątek konfiskowany świątyniom pogańskim po części włączany był do cesarskiego res privata, po części przekazywany osobom prywatnym (najczęściej wysokim urzędnikom w uznaniu ich zasług) oraz Kościołowi ${ }^{5}$. Taki mechanizm przepływu nieruchomości świątynnych konfiskowanych przez cesarzy, dostrzegamy również poprzez pryzmat postanowień edyktu restauracyjnego, wydanego przez cesarza Juliana Apostatę. Wraz z objęciem rządów przez Jowiana ów rewindykowany majątek świątynny ponownie został im odebrany lecz tym razem w całości został włączony do cesarskiego res privata ${ }^{6}$.

\section{Przypadki burzenia świątyń pogańskich w późnej strożytności. Pierwsze} przypadki burzenia świątyń źródła rejestrują już w okresie panowania Konstantyna Wielkiego ${ }^{7}$. Zniszczono wówczas znane z uprawianej w nich prostytucji sakralnej świątynie Afrodyty w Heliopolis, w Aphaka ${ }^{8}$ oraz w Aelia (Jerozolimie $)^{9}$, świątynię Apollina w Delfach ${ }^{10}$, świątynię Asklepiosa w Ajgaj w Cylicji ${ }^{11}$, świątynię Hermesa w Antiochii, Saturna w Aleksandrii oraz bliżej

${ }^{2}$ Libanios, Oratio XXX 49, tłum. L. Małunowiczówna: Libanios, Wybór mów, BN ser. II 85, Wroclaw 1953, 251.

${ }^{3}$ Por. Oratio XXX 43, Małunowiczówna s. 247.

${ }^{4}$ Por. A. H. M. Jones, Greek City from Alexander to Justinian, Oxford 1980, 227-229.

5 Ammian Marcellinus, Res gestae XXII 4; Libanios, Oratio XXX 38.

${ }^{6}$ Codex Theodosianus VI 13, 3; ibidem X1,8, ed. Th. Mommsen, Berolini 1905 (dalej cyt. CTh).

${ }^{7}$ Eusebius, Vita Constantini III 54 (dalej cyt. VC); Sozomenus, HE I 8; ibidem, II 5. Według Teodoreta z Cyru (HE V 20), Konstantyn wystąpił przeciw pogaństwu zakazując składania ofiar oraz nakazując zamknięcie ale nie niszczenie świątyń; Theophanes, Chronographia 5816 (ed. The Chronicle of Theophanes Confessor. Byzantine and Near Eastern History ad 284-813, ed. and transl. by C. Mango - R. Scott, Oxford 1997); por. także Hieronymus, Chronicon sub anno 331(ed. Die Chronik des Hieronymus, hrsg. von R. W. O. Helm, Berlin 1984, s. 233): „Edicto Constantini gentilium templa subversa sunt"; zob. także CTh XV 1, 3; Eusebius, VC III 54; Sozomenus, HE II 5; Socrates, HE I 18.

${ }^{8}$ Eusebius, VC III 55-58; Sozomenus, HE II 5; Theodoretus, HE III 6.

9 Theophanes, Chronographia 5817; por. także M. Joint-Lambert, Jérusalem israélite, chrétienne, musulmane, Paris 1956, s. 87.

${ }^{10}$ Sozomenus, HE II 5.

11 Ibidem, II 5; Theophanes, Chronographia 5816; Libanios (Oratio XXX 39) utrzymuje, iż tę świątynie zburzono dopiero w czasach Konstancjusza. 
nie określoną świątynię w syryjskiej Aretuzie ${ }^{12}$. W jaki sposób można tłumaczyć tę wybiórczość w przypadku burzonych świątyń pogańskich? Według poganina Eunapiosa, cesarz Konstantyn nakazał zniszczyć tylko te świątynie, które cieszyły się szczególnym szacunkiem i czcią pogan ${ }^{13}$. Tę uwagę odnieść można do kultu Afrodyty i jej świątyń w Heliopolis, Aphaka oraz w Aelia, gdzie świątynia Afrodyty stała na miejscu mieszczącym Grób Pański ${ }^{14}$. Opinię Eunapiosa odnieść można również do Asklepejonu w Ajgaj w Cylicji, który choć nie był najbardziej znany ze świątyń Asklepiosa, to jednak związany był z działalnością Apoloniusza z Tiany, którego kult był mocno zwalczany przez apologetów chrześcijańskich ${ }^{15}$. Rozpatrując interesującą nas tu kwestię nie należy zapominać, iż do naszych czasów dochowała się jedynie pamięć o zniszczeniu przez chrześcijan tych najbardziej znanych świątyń. O zamknięciu bądź zburzeniu mniej znanych przybytków dowiadujemy się jedynie z przypadkowych relacji. Nie do końca również jest jasny charakter i zasięg łupienia na polecenie cesarza skarbców świątynnych przez specjalnych urzędników ${ }^{16}$.

Bardziej zdecydowaną politykę wobec świątyń prowadził Konstancjusz II. $\mathrm{Na}$ jego rozkaz zamknięto wiele świątyń pogańskich, z których większość została przekazana miejscowym biskupstwom ${ }^{17}$. W czasach Konstancjusza II zburzono ponadto: świątynię Apollina i Zeusa w Cezarei Kapadockiej ${ }^{18}$, Artemidy w licyjskiej Myrze ${ }^{19}$, świątynię Mena w Antiochii Pizydyjskiej ${ }^{20}$ oraz bliżej nie określoną w źródłach świątynię w Lampsakos ${ }^{21}$.

12 Theodoretus, HE III 6.

13 Philostratus and Eunapius, The Lives of the Sophists, ed. and transl. by W. C. Wright, London - Cambrigdde 1961, s. 378; por. także H. Saradi-Mendelovici, Christian Attitudes toward Pogan Monument in Late Antiquity and their Legacy in Later Byzantine Centuries, „Dumbarton Oaks Papers" 44(1990) 48 i nn.

${ }^{14}$ Eusebius, VC III 26-29.

15 Por. M. Dzielska, Apolloniusz z Tiany. Legenda i rzeczywistość, Kraków 1983, s. 42, 115; zob. także: J. Geffcken, Der Ausgang des griechisch-römischen Heidentums, Darmstadt 1963, ss. 95 i 279 nota 42.

${ }^{16}$ Por. Libanios, Oratio II 30; Oratio XXX 6, 37; Eusebius, VC III 54. Cesarz Konstantyn pomimo swej prochrześcijańskiej polityki wybudował w Konstantynopolu kilka pogańskich świątyń (Zosimos, Historia nova II 31, tłum. H. Cichocka: Historia nowa, Warszawa 1993, 107), co też w opinii późniejszych autorów chrześcijańskich uchodziło za wymysł pogan, por. np. Augustyn, O Państwie Bożym V 25, tłum. W. Kornatowski, Warszawa 1977, 300. Również na prowincji jeszcze w 2. poł. IV wieku budowano pogańskie świątynie, por. W. Müller-Wiener, Mittelalterlichen Befestigungen im südlichen Jonien, „Istanbuler Mitteilungen” 11(1961) s. 38; zob. także: J. Geffcken, Der Ausgang..., s. 95.

${ }^{17}$ CTh XVI 10, 4; Sozomenus, HE III 17. O łupieniu świątyń pogańskich przez cesarskich urzędników, por. Hilarius Pictaviensis, Contra Constantium 10.

${ }^{18}$ E. Kirsten, Cappadocia, RAC II 885.

19 V. Schultze, Altchristliche Städte und Landschaften, Bd. II/1 (Kleinasien), Gütersloh 1922, s. $201,444$.

${ }^{20}$ Tamże, Bd. II/2, Gütersloh 1926, s. 223.

${ }^{21}$ Tamże, Bd. II/2, s. 444. 
Państwo odstąpiło od wrogiej polityki wobec kultów pogańskich po wstąpieniu na tron Juliana Apostaty (361 rok). Nowy cesarz rozpoczął swe rządy od wydania edyktu restauracyjnego nakazującego otwarcie wszystkich świątyń ${ }^{22}$. Natomiast Kościołowi i osobom prywatnym nakazał zwrot zagrabionych bądź też przejętych nawet za przyzwoleniem cesarskim świątyń i należących do nich majątków ${ }^{23}$. Tym, którzy przyczynili się do zniszczenia pogańskich świątyń (a więc w szczególności chrześcijanom), cesarz nakazal ich odbudowę bądź wypłacenie odpowiednich odszkodowań ${ }^{24}$. Jednakże przypadki zniszczenia świątyń pogańskich źródła rejestrują również w okresie panowania cesarza Julia$\mathrm{na}^{25}$. Jego następca, cesarz Jowian, nakazał niszczyć świątynie, których budowę nakazał jego poprzednik ${ }^{26}$.

Nie do końca jest jasna polityka Walensa wobec dawnych kultów. Według Teodoreta z Cyru, władca ten zezwolił w rządzonych przez siebie prowincjach wschodnich na swobodne praktykowanie kultów pogańskich oraz obchodzenie świą ${ }^{27}$. Nie należy jednak zapominać, iż relacja ta wyszła spod pióra nieprzychylnego Walensowi biskupa, który być może chciał tu pokazać, iż cesarz liberalny wobec pogan, jednocześnie bezwzględnie tępił ortodoksję. Niemniej do liberalnej polityki religijnej Walensa nawiązuje również Libaniusz ${ }^{28}$.

Kolejne przypadki burzenia świątyń źródła rejestrują w okresie panowania cesarza Teodozjusza Wielkiego ${ }^{29}$. Lokalni biskupi ośmieleni i zachęceni polityką cesarza wobec religii pogańskich zaczęli na własną rękę niszczyć świątynie. Zburzono wówczas świątynie w Edessie, Apamei (i jej okolicach), Palmyrze, w miastach Arabii: Petrze i Areopolis, miastach Libanu oraz palestyńskiej

${ }^{22}$ Sozomenus, HE V 11; Ammianus Marcellinus, Rerum gestarum XXII 5; Socrates, HE III 1; Theodoretus, HE III 6.

${ }^{23}$ Libanios, Epistula 673 (ed. Libanius, Opera, vol. X, ed. R. Foerster, Leipzig 1921).

${ }^{24}$ Gregorius Nazianzenus, Oratio IV 90; Sozomenus, HE V 5; Theodoretus, HE III 6; Libanios, Oratio XII 69; XVIII 126; idem, Epistula 624; Zonaras, Epitome historiarum, XIII 12 (ed. T. Büttner - Wobst, Bonn 1897). Por. także W. Ceran, Kościót wobec antychrześcijańskiej polityki cesarza Juliana Apostaty, Łódź 1980, 113-114; Sz. Olszaniec, Julian Apostata jako reformator religijny, Kraków 1999, 18-29.

${ }_{25} \mathrm{Na}$ początku jego panowania chrześcijanie w Cezarei Kapadockiej zniszczyli miejscowy Tychejon (Gregorius Nazianzenus, Oratio IV 92; Sozomenus, HE V 4). W 363 roku spłonęła również, lecz jak podkreśla to Ammian Marcellin nie z inicjatywy chrześcijan, świątynia Apollina w Daphne w pobliżu Antiochii, por. Ammianus Marcellinus, Rerum gestarum, XXII 12-13; Sozomenus, HE V 19-20; Theodoretus, HE III 10; Rufinus, HE I 35; Gregorius Nazianzenus, Oratio V 40; Joannes Chrysostomus, De Sancto Babyla contra Julianum et gentiles 16, 87-89, w: The Emperor Julian Panegyric and Polemic, ed. S. N. C. Lieu, Liverpool 1989, 65-66; G. Downey, A History of Antioch in Syria from Seleucos to the Arab Conquest, Princeton 1961, 387-388.

${ }^{26}$ Libanios, Epistula 1489 (ed. R. Foerster, vol. XI); Socrates, HE III 24.

27 Theodoretus, HE V 20; Jacobus Edessenus, Chronica minora 224, CSCO 5-6, Leiden 1907; Michael le Syrien, Chronicon, I 292, ed. J. B. Chabot, Paris 1899.

${ }^{28}$ Libanios, Oratio XXX 8.

29 Zosimos, HN IV 37; Libanios, Oratio XXX 46. 
Rafie $^{30}$. W 391 roku z inicjatywy miejscowego biskupa Teofila doszło do zniszczenia kilku świątyń aleksandryjskich, w tym przede wszystkim słynnego Serapejonu. Biskup uderzając na świątynie pogańskie w 391 roku zasłaniał się cesarskim rozporządzeniem, wydanym dla Aleksandrii, nakazującym zamknięcie tamtejszych świątyń. W opinii współczesnych Teofil uderzył na aleksandryjskie świątynie chcąc uzyskać w taki sposób spolia do budowy kościołów w Aleksandrii ${ }^{31}$.

Nie inaczej było również w czasach Arkadiusza. Na przełomie 401-402 roku arcybiskup Konstantynopola, Jan Chryzostom, doprowadził do zniszczenia świątyni Artemidy w Efezie oraz innych świątyń we Frygii, Fenicji oraz Sy$\mathrm{rii}^{32}$. Chryzostom pośrednio przyczynił się również do zburzenia przez biskupa Porfyriusza świątyń pogańskich w Gazie w 402 roku $^{33}$. Akcje przeciw świąty-

30 Sozomenus, HE VII 15; Nicephorus Callistus, HE XII 27, PG 146, 829-833; Theodoretus, HE V 21; Libanios, Oratio XXX 44-45. Por. także B. Gąssowska, Maternus Cynegius, Praefectus Praetorio Orientis and the Destruction of the Allat Temple in Palmyra, „Archeologia” 33(1982) s. 121. O burzeniu świątyń w okolicach Antiochii, por. Libanios, Oratio XXX 6, 9, 29. Burzenie świątyń w V wieku w Bitynii, por. Callinicos, Vita Hypatii 30 ed. A. J. Festiugiere, w: Les Moines d'Orient, t. 2: Les moines de la région de Constantinople, Paris 1961.

${ }^{31}$ Eunapius, dz. cyt, s. 422; Rufinus, HE II 22-23. Por. także Isidorus, Epistula I 152. Teofil sprowokowawszy zajścia w Aleksandrii zapewnił sobie zbrojną pomoc mnichów nitryjskich, por. między innymi Apoftegmata Patrum: Abba Besarion 4 (159), thum. M. Borkowska, t. 1: Gerontikon, Kraków 1994, 184; ibidem, Teofil Arcybiskup, 3 (306); Theodoretus, HE V 22; F. Thélamon, Paiens et chrétiennes au $I V^{e}$ s. L'apport de l'Histoire Ecclésiastique de Rufin d'Aquilée, Paris 1981, s. 254; Ch. Haas, Alexandria in Late Antiquity. Topography and Social Conflicts, Baltimore and London 1996, s. 146. O wypadkach aleksandryjskich z 391 roku donoszą takze wczesnobizantyńskie kroniki, w tym także Kronika Aleksandryjska: „W tym roku (109 ery Dioklecjana) świątynie Greków zostały zniszczone" (A. Bauer - J. Strzygowski, Eine Alexadrische Weltchronik, Wien 1906, s. 74). Jan Malalas (Chronicon, XIII 48, ed. and transl. by E. Jeffreys, M. Jeffreys, R. Scott, Melbourne 1986) zburzenie Serapejonu w Aleksandrii błędnie przesuwa na czasy cesarza Arkadiusza. W tym samym czasie splądrowano również okoliczne świątynie Izydy, por. Zacharias, Vita Severii 17, ed. M. A. Kugener, PO 2/1, 64-67; PO 2/1; Joannes Moschos, Pratum spirituale $105-$ 106; por. także F. Trombley, dz. cyt., vol. I, s. 137; vol. II, s. 5-6 oraz Ch. Haas, dz. cyt., s. 211.

${ }^{32}$ Frygia: Joannes Chrysostomus, In Acta Apostolorum hom. 18, 5; Fenicja: Theodoretus, HE V 29, gdzie się stwierdza, że Chryzostom do burzenia świątyń w Fenicji wysłał mnichów. Owa akcja finansowana była przez bogate chrześcijanki ze stolicy. Na ten temat por. także Joannes Chrysostomus, Epistulae 28, 51, 53, 54, 55, 69, 123, 126, 221. O akcji Chryzostoma przeciwko świątyniom w Efezie, Frygii i w Fenicji por. Proklos, Homilia 20, 3, PG 65, 832-834: „Każde z miejsc uwolnił [Chryzostom - I. M.] od błędu. W Efezie obrabowal świątynię Artemidy, we Frygii natomiast odebrał matce Bogów [Kybele - I. M.] jej synów". Echa akcji wymierzonej przeciw świątyni Artemidy w Efezie odnajdujemy także u Ammoniusza z Aleksandrii: Fragmenta in Acta Apostolorum, PG 85, 1577 A-B oraz u samego Jana Chryzostoma: In Acta Apostolorum hom. 42, 2. Na temat akcji antypogańskich Jana Chryzostoma por. także P. Ch. Baur, Der heilige Johannes Chrysostomus und seine Zeit, Bd. 2, München 1931, 132-133.

${ }^{33}$ Marcus Diakonus (Vita Porphyrii, 64, ed. H. Grégoire et P. Kugener, Paris 1930) wymienia miejscowe świątynie, które wówczas zniszczono: świątynia Heliosa, Afrodyty, Apollina, Kory, Hekate, Hery, Tyche oraz świątynia Zeusa Marnasa. 
niom na Wschodzie podejmowano także w połowie $\mathrm{V}$ wieku ${ }^{34}$. Nie zawsze jednak posiadały one sankcje prawne, jak to było chociażby w przypadku działań Szenute z Atrypy w Egipcie ${ }^{35}$ oraz Rabulli, biskupa Edessy ${ }^{36}$. Najprawdopodobniej również $\mathrm{w}$ połowie $\mathrm{V}$ wieku zburzono świątynię Zeusa w Olim$\mathrm{pii}^{37}$.

Choć być może powyższe krótkie zestawienie przypadków destrukcji świątyń pogańskich w późnej starożytności może przyprawić o wrażenie, iż w interesującym nas okresie definitywnie wydano na nie wyrok, to w rzeczywistości tylko cześć świątyń pogańskich, z reguły te najbardziej znane, została wówczas zniszczona. Dla większości z nich bowiem znaleziono inne sposoby wykorzystania. Przejdźmy więc do ich omówienia.

3. Powtórne wykorzystanie świątyń pogańskich do celów publicznych. Byłe świątynie często wykorzystywane były w celach publicznych. Jednakże jedyne znane nam rozporządzenie cesarskie nakazujące wykorzystywać zamknięte świątynie do celów publicznych (ad usum publicum) wydane zostało w 407 roku w Kartaginie ${ }^{38}$. Libaniusz w mowie Pro templis wykazując bezmyślność niszczenia świątyń w celu wykorzenienia dawnych kultów, stwierdza, iż budowle te można by wykorzystać do innych celów, zbierając w nich chociażby podatki od obywateli ${ }^{39}$. Z jego listów i mów dowiadujemy się także o sposobach powtórnego wykorzystania kilku świątyń antiocheńskich: w krużganku świątyni Dionizosa oraz w świątyni Ateny urządzono salę rozpraw sądowych ${ }^{40}$, w miejscowym Tychejonie natomiast zorganizowano szkołę retoryki ${ }^{41}$, której działalność zawieszono już w czasach Juliana. Nie udało się jednak przywrócić jej pierwotnej funkcji. Dlatego też, jak utrzymuje Libaniusz, stojąca bezpańsko świątynia była miejscem, w którym czasami ukrywali się kupcy przed nękającymi ich urzędnikami podatkowymi ${ }^{42}$. O losie świątyń antiocheńskich donosi również Malalas, według którego miejscowa świątynia Muz została przebudowana na budynek praetorium ${ }^{43}$.

${ }^{34}$ Por. CTh XVI 10, 25.

35 Por. Besa, The Life of Shenute 83, ed. by D. N. Bell, Kalmazoo, Michigan 1983; J. Leipold, Shenute von Atripe und die Entstehung des national ägyptischen Christentums, Leipzig 1903, $178-$ 179, 181.

${ }^{36}$ Por. E. Kirsten, Edessa, RAC IV 563.

37 Por. P. Thrams, Christianiesierung des Römerreiches und heidnischer Wiederstand, Heidelberg $1992,114$.

${ }^{38}$ CTh XVI 10 19; por. także: Constitutio Sirmondiana 12.

${ }^{39}$ Libanios, Oratio XXX 42.

40 Idem, Oratio XLV 26 (świątynia Dionizosa); idem, Epistula 847 (świątynia Ateny).

${ }^{41}$ Idem, Oratio I 102; idem, Epistula 88.

${ }^{42}$ Idem, Epistula 1406.

43 Joannes Malalas, Chronicon XIII 4. 
Analogiczne przykłady odnajdujemy również w Konstantynopolu. Tamtejsze świątynie pogańskie wybudowane przez Konstantyna, zamknięto już za panowania Konstancjusza II. Dopiero jednak Teodozjusz I zadecydował o ich przeznaczeniu. Świątynię Heliosa przebudowano na ksenodochium, świątynię Afrodyty w wozownię praefecta praetorio, w świątyni Artemidy natomiast urządzono dom hazardowy. W świątyni Kastora i Polluksa założono przytułek dla biednych, w którym nocleg znajdywały między innymi miejscowe prostytutki $^{44}$. Szpital zorganizowano również $\mathrm{w}$ jednej z bliżej nie określonych świątyń w $\operatorname{Sardes}^{45}$.

4. Powtórne wykorzystywanie świątyń dla celów prywatnych. W posiadanie zamkniętych świątyń często wchodziły osoby prywatne. W jaki sposób świątynie w interesującym nas okresie przechodziły w prywatne ręce? Cesarz konfiskując budowle świątynne i przynależne do nich majątki z reguły tylko część z tego zostawiał sobie, resztę natomiast rozdawał bądź sprzedawał osobom prywatnym ${ }^{46}$. Konkretne przypadki relacjonuje Libaniusz. Według niego Hermogenes, magister militum w czasach Konstancjusza II, w uznaniu swych zasług otrzymał w Tyrze dom, który powstał z przebudowy świątyni. Później poganie z Tyru, wykorzystując rządy sprzyjającego starej religii cesarza Juliana, dążyli do odzyskania tej budowli ${ }^{47}$. Podobnie było w kolejnym przypadku relacjonowanym przez Libaniusza: od synów Thelasiosa, praefecta praetorio Orientis w latach 351 - 363, zażądano zwrotu domu, który również powstał z przebudowanej świątyni. Mało tego: od dotychczasowych właścicieli domu domagano się również, aby zajmowany przez siebie dom ponownie przebudowali na świątynię ${ }^{48}$. Z innego listu Libaniusza wynika, iż ci sami synowie Thelasiosa na terenie prowincji Syria Euphratensis posiadali dom, który również powstał na skutek przebudowy świątyni ${ }^{49}$. Także w Cyrenie tamtejsze świątynie Demeter oraz Apollina przebudowano na domy mieszkalne, przy czym czynnikiem, który o tym zadecydował, był fakt ich częściowego zniszczenia na skutek trzęsienia ziemi ${ }^{50}$. W latach dziewięćdziesiątych IV wieku w aleksandryjskim Tychejonie urządzono tawernę ${ }^{51}$.

W wielu przypadkach zwrot dawnych świątyń pogańskich przez osoby prywatne był niemożliwy, przez co też na ich właścicieli w czasach Juliana

44 Ibidem, XIII 39.

${ }^{45}$ V. Schultze, dz. cyt., Bd. II/2, s. 150.

${ }^{46}$ Libanios, Oratio XXX 38-39; Ammianus Marcellinus, Rerum gestarum XX 4; por. także CTh X 1,8 .

${ }^{47}$ Libanios, Epistula 828.

${ }^{48}$ Idem, Epistula 1364.

49 Idem, Epistula 1404.

${ }^{50}$ R. Goodchild, Cyrene and Apollonia, London 1959, 57; D. Rouques, Synèsios de Cyréne et la Cyrénaique du Bas Empire, Paris 1987, 319.

51 Anthologia Palatina IX: Epigramma 180, ed. W. R. Paton, New York - London 1916-1918. 
Apostaty, kiedy realizowano edykt restauracyjny, nakładano odpowiednio wysokie kary pieniężne, $\mathrm{z}$ których dochód miał być przeznaczony na budowę nowych świątyn ${ }^{52}$.

5. Przebudowa świątyń pogańskich w kościoły. Częstym sposobem wykorzystywania dawnych świątyń była ich przebudowa na kościoły. Problem adaptacji świątyń pogańskich przez chrześcijaństwo w późnej starożytności był już szeroko omawiany w dotychczasowej literaturze, dlatego też poza wskazaniem na odpowiednie dane bibliograficzne, ograniczymy się tu tylko do poczynienia kilku uwag ${ }^{53}$.

Źródła literackie, w odróżnieniu od danych archeologicznych, nie podają zbyt wielu informacji o przejmowaniu świątyń pogańskich przez Kościół. Pierwsze takie przypadki miały miejsce w Aleksandrii w końcu lat dwudziestych IV wieku ${ }^{54}$. Inne przykłady adaptacji to: świątynia Augusta w Ankyrze ${ }^{55}$, świątynie ateńskie - Partenon w kościół pod wezwaniem Marii Dziewicy ${ }^{56}$ i Tezejon w kościół pod wezwaniem św. Jerzego ${ }^{57}$, także Erechtejon ${ }^{58}$, świątynia Artemidy oraz druga, bliżej nie określoną świątynia w Gerasie w Dekapolis ${ }^{59}$, bliżej nie określona w źródłach świątynia w Nazjanzie ${ }^{60}$, świątynia Dionizosa ${ }^{61}$ oraz Mitry w Aleksandrii ${ }^{62}$, świątynie Zeusa w Damaszku ${ }^{63}$ i w Heliopolis ${ }^{64}$, świą-

52 Libanios, Oratio XVIII 126.

53 Por. F. W. Deichmann, Frühchristliche Kirchen in antiken Heiligtümer, ,Jahrbuch des Deutschen Archäologischen Instituts" 54(1939) 105 i nn.; idem, Christianisierung II (der Monumente), RAC II 1231-1232; R. P. C. Hanson, The Transformation of Pagan Temples into Churches in the Early Christian Centuries, ,Journal of Semitic Studies” 23(1978) 257-267.

${ }^{54}$ Eutychius, Annales 433-435, PG 111, 1005; Epiphanios, Panarion haer., LXIX; Socrates, HE VII 15; Athanasius Alexandrinus, Apologia ad Constantium Imperatorem 14-15; idem, Historia Arianorum 55.

55 V. Schultze, dz. cyt., Bd. II/2, s. 406; C. Foss, Ankyra, RAC Suppl. III 458-459.

${ }^{56}$ F. W. Deichmann, Frühchristliche..., s. 112; K. Setton, The Archeology of Medieval Athens, w: Essais in Medieval Life and Thought Presentet to Honour of Austin Patterson Evans, New York 1955, 248; A. Frantz, From Paganism to Christianity in the Temples of Athens, „Dumbarton Oaks Papers" 19(1965) 201.

57 F. W. Deichmann, Frühchristliche..., s. 112; K. Setton, dz. cyt., s. 248.

58 F. W. Deichmann, Früchristliche..., s. 131.

${ }^{59}$ C. Krealing, Gerasa, City of the Decapolis, New Haven 1938, 138, 210.

${ }^{60}$ Gregorius Nazianzenus, Epigramma 30, PG 38, 99.

61 Sozomenus, HE VII 15.

${ }^{62}$ Socrates, HE V 16.

${ }^{63}$ Chronicon Paschale 379, ed. Chronicon Paschale 284-628 A. D., transl. by M. Whitby and M. Whitby, Liverpool 1989, 50; R. Dussaud, Le temple de Jupiter Damscénien et ses transformations aux époques chrétienne et musulmane, „Syria” 3(1922) 219-250.

${ }^{64}$ Chronicon Paschale 379 (s. 50); Joannes Ephesinus, Kirchengeschichte, III, 27, hrsg. von J. M. Schönfelder, München 1862; V. Schultze (Geschichte des Untergangs des griechisch-römischen Heidentums, Bd. II, Jena 1892 252) utrzymuje, iż miejscowi chrześcijanie przejąwszy świątynie Zeusa w Heliopolis, dla swych potrzeb wykorzystywali zaledwie jej przedsionek. 
tynia Dionizosa w Gangra w Paflagonii ${ }^{65}$, świątynia Artemidy w Sardes w Lidii $^{66}$, bliżej nie określona świątynia w Eleusa w Kylikii ${ }^{67}$, świątynia Afrodyty w Afrodysias w Karii ${ }^{68}$, wyrocznie w Dodonie i w Dydymie ${ }^{69}$, antiocheński Tychejon (rok 438) ${ }^{70}$ itd.

Jakie czynniki przemawiały za adoptowaniem przez starożytny Kościół świątyń pogańskich? Istotny był z pewnością czynnik ekonomiczny. W obliczu problemów finansowych poszczególnych biskupstw oraz wzrostu liczby wyznawców coraz bardziej odczuwalny był brak odpowiedniej liczby kościołów. Równie ważne były przesłanki ideologiczne. Łatwiej było bowiem w mniemaniu współczesnych przyciągnąć pogan do chrześcijaństwa adoptując w tym celu czczone przez nich już wcześniej miejsca kultu oraz znaną im symbolikę. W interesującym nas okresie na kościoły przebudowywano nie tylko świątynie pogańskie, lecz również żydowskie synagogi ${ }^{71}$, czasami nawet budynki użyteczności publicznej ${ }^{72}$. Kościoły wznoszono również w gajach czczonych przez pogan oraz przez żydów ${ }^{73}$.

6. Inne sposoby wykorzystywania nieczynnych świątyń pogańskich. Niektóre spośród świątyń wykorzystywano również do celów gospodarczych. W kilku $\mathrm{z}$ nie wymienionych $\mathrm{z}$ nazwy przez Libaniusza świątyniach antiocheńskich składowano drewno oraz zboż $\mathrm{e}^{74}$. O wręcz manufakturowym wykorzystywaniu świątyń świadczy przypadek świątyni Artemidy w Sardes, w której wybudowano piec do wypalania wapna wykorzystując w tym celu antyczne posągi ${ }^{75}$. Bliżej nie określony charakter gospodarczego wykorzystania zamkniętej świątyni odnajdujemy także w przypadku świątyni Artemidy w Gerazie ${ }^{76}$.

7. Odzyskiwanie spolia ze zburzonych świątyń. Czasami świątynie burzono, a uzyskany z rozbiórki budulec wykorzystywano do remontu bądź wznoszenia

${ }^{65}$ V. Schultze, Altchristliche..., Bd. II/1 s. 202.

66 Tamże, Bd. II/2, s. 149.

${ }^{67}$ M. Gough, A Temple and a Church at Ayas (Cilicia), „Anatolian Studies” 4(1954) s. 57.

68 V. Schultze, Altchristliche..., Bd. II/2, s. 162.

${ }^{69}$ P. Thrams, dz. cyt., s. 110; 112-114.

${ }^{70}$ Evagrius Scholasticus, HE I 16; por. także W. Eltester, Kirchen Antiochias im IV Jahrhundert, „Zeitschrift für Neutestamentliche Wissenschaft” 36(1937) s. 271.

${ }^{71}$ Przykłady takich adaptacji odnajdujemy w Gerazie (C. Krealing, dz. cyt., s. 234), Edessie (Chronicon Edessenum 51), Antiochii (Evagrius, HE I 13) oraz w Azji, Frygii, Karii i Lydii (Joannes Ephesinus, The Lifes of the Eastern Saints 47, PO 18, 681).

${ }^{72}$ F. W. Deichmann, Christianisierung..., s. 1235-1237.

${ }_{73}$ Na przykład Gaj Mamre, por. Sozomenus, HE II 5; Eusebius, VC III 51; Socrates, HE I 18.

74 Libanios, Oratio VII 10.

${ }^{75}$ G. M. A. Hanfmann, Sardis und Lydien, ,Meinzer Abhandlungen. Geistes- und Sozialwissenschaftliche Klasse" 4(1960) 535.

${ }^{76}$ C. Krealing, dz. cyt., s. 233. 
budowli publicznych, prywatnych oraz w mniejszym już stopniu kościołów i kaplic męczenników. Czynnikami jakie sprzyjały podejmowaniu decyzji o rozbieraniu świątyń na spolia były nie tyle zniszczenia dokonane przez chrześcijan, lecz szkody powstałe na skutek trzęsień ziemi, szczególnie częstych na Wschodzie w późnej starożytności.

W źródłach odnajdujemy najczęściej tylko lakoniczne informacje na temat wykorzystywania spolia odzyskanego z rozebranych świątyn ${ }^{77}$. Z relacji Sozomena wynika, iż wiele spośród świątyń pogańskich przekazanych Kościołowi przez Konstancjusza II zostało rozebranych na spolia ${ }^{78}$. Na budulec rozebrane została m.in. świątynia Serapisa w Aleksandrii oraz inne miejscowe świątynie, na które uderzyli w 391 r. miejscowi chrześcijanie ${ }^{79}$. Marmurem odzyskanym z rozbiórki adytonu w gazeńskim Marnejonie, miejscowy biskup Porfyriusz rozkazał wybrukować plac, na którym stał Marnejon, tak aby „był on deptany przez mężczyzn, kobiety, psy, świnie i wszelki rodzaj bydła". Dlatego też gazeńscy poganie, szczególnie kobiety, jeszcze w wiele lat po zburzeniu Marnejonu, omijali ten plac, aby nie stąpać po świętych kamieniach ${ }^{80}$. Natomiast do budowy nowej świątyni - bazyliki eudoksjańskiej wykorzystano kamień z pobliskich wzgórz ${ }^{81}$.

Spolia z rozebranych świątyń pogańskich często zakupywane były przez osoby prywatne. Tak było chociażby w przypadku bliżej nieznanego nam Theodulosa, który w Antiochii w czasach Konstancjusza II ze spolia odzyskanego z rozebranej świątyni wybudował sobie dom, który jednak skonfiskowano w czasach Juliana Apostaty ${ }^{82}$.

Również kilka świątyń w Cyrenie zostało rozebranych na spolia. Na budulec rozebrano między innymi zniszczoną na skutek trzęsienia ziemi świątynię Apollina; część uzyskanego z niej spolia wykorzystano do renowacji budowli publicznych, a marmurem pozyskanym z rozbiórki ołtarza Apollina wyłożono posadzkę w miejscowych termach ${ }^{83}$. Na budulec rozebrano również miejscową świątynię Zeusa ${ }^{84}$. Inną natomiast, bliżej nie określoną świątynię, włączono w system miejskich obwarowañ ${ }^{85}$.

${ }^{77}$ Por. chociażby: Theodoretus, Graecarum affectionum curatio VIII 68; Sozomenus, HE VI 20; Socrates, HE IV 24.

78 Sozomenus, HE III 17.

79 Socrates, HE V 16; Rufinus, HE II 27-28. Inaczej utrzymywał Sozomen, HE VII 15.

${ }^{80}$ Marcus Diaconus, Vita Porphyrii, 76. Według F. Trombleya (dz. cyt., vol. I, s. 203) marmurem odzyskanym z efeskiego Afrodyzjonu wyłożono posadzkę kościoła wybudowanego na miejscu świątyni. O wznoszeniu ze spolia kościołów w Syrii w interesującym nas okresie por., G. Tschalenko, Villages antiques de la Syrie du Nord: le masif du Bélus á l'époque romaine, t. 1-3, Paris 1953-1958.

${ }^{81}$ Marcus Diaconus, Vita Porphyrii, 79.

${ }^{82}$ Idem, Epistula 724. Por. także idem, Oratio VII 10, lub Epistulae 717, 763, 819, 1411.

${ }^{83}$ K. Goodchild, dz. cyt., s. 58.

84 Tamże, s. 71.

85 Tamże, s. 59 
Rozpatrując przyczyny rozbierania świątyń pogańskich na spolia w późnej starożytności należy brać pod uwagę szereg czynników, jak chociażby wielkość populacji chrześcijan w danym mieście bądź okolicy, zamożność miejscowego biskupstwa, sława świątyni, która często wychodziła poza granicę prowincji (jak na przykład Serapejon czy Marnejon). Faktem jednak jest, iz inne, niemniej znane świątynie Wschodu, mimo ekspansji chrześcijaństwa przetrwały. Poznając atmosferę towarzyszącą chrystianizacji Imperium w interesującym nas okresie nie należy dziwić się, iż doszło do zburzenia gazeńskiego Marnejonu czy też aleksandryjskiego Serapejonu. Ta ostatnia świątynia na skutek toczonych przed nią walk w 391 roku urosła do rangi swoistego symbolu: dla pogan był to symbol oporu wobec, jakby nie patrzeć, agresywnych poczynań miejscowego biskupa, dla chrześcijan natomiast Serapejon było świątynią jednego z pogańskich idoli, podczas niszczenia której zginęło wielu chrześcijan. Również gazeński Marnejon musiał spotkać podobny los. Po pierwsze ze względu na „bezeceństwa”, jakich poganie rzekomo dopuszczali się w tej świątyni, po drugie fakt, iż jeszcze przed jej zburzeniem cesarzowa Eudoksja wyraziła wolę, aby na miejscu zburzonego Marnejonu wybudowano za ofiarowane przez nią pieniądze okazałą bazylikę ${ }^{86}$. Mimo to jednak wielu spośród gazeńskich chrześcijan uważało, iż Marnejon należy tylko „oczyścić od demonów” i przebudować na kościól ${ }^{87}$.

Wiele spośród zniszczonych i ograbionych świątyń zostało rozebranych na budulec, nie tyle z polecenia władców, co przede wszystkim z inicjatywy okolicznej ludności ${ }^{88}$. Pierwsze znane nam rozporządzenie cesarskie dotyczące sposobów wykorzystywania budulca ze zniszczonych świątyń pogańskich pochodzi dopiero z 397 roku. W rozporządzeniu kierowanym do komesa Wschodu, rezydującego w Antiochii, cesarz Arkadiusz nakazuje, aby materiał budowlany ze zburzonych świątyń wykorzystać do naprawy dróg, murów miejskich i akweduktów ${ }^{89}$. Być może jednak rozporządzenie to należałoby wiązać nie z destrukcyjnymi akcjami chrześcijan, lecz ze szkodami powstałymi w Antiochii i jej okolicy na skutek trzęsień ziemi.

W literaturze omawiającej destrukcje świątyń pogańskich w późnej starożytności pomija się kwestię technicznych trudności związanych z burzeniem świątyń pogańskich, które często były pokaźnych rozmiarów. Marcellus, biskup syryjskiej Apamei, chcąc zburzyć świątynię Zeusa w Aulon, wynajął rzemieślników, którzy wykonując podkop pod frontową część świątyni zdołali zburzyć ledwie jej część ${ }^{90}$. Poza tym burzenie świątyń było również dość kosz-

${ }^{86}$ Marcus Diaconus, Vita Porphyrii 43.

${ }^{87}$ Tamże, 66.

88 Por. chociażby Libanios, Oratio XVIII 126; idem, Epistula 724; zob. także P. Petit, Libanius et la vie municipale à Antioche au IV ${ }^{e}$ s. après J. C., Paris 1956, s. 209.

${ }^{89}$ CTh XV 1, 36.

${ }^{90}$ Theodoretus, HE V 21; Sozomenus, HE VII 15; Nicephorus Callistus, HE XII 27; por. także analogiczną relację Libaniosa, Oratio XXX 38. 
townym przedsięwzięciem i z pewnością nie decydowano się na ich rozbiórkę tylko z pobudek religijnych. Oczywiście znamy również przypadki (np. Serapejon w Aleksandrii, Marnejon w Gazie), kiedy do rozbiórki świątyni wykorzystywano miejscowych chrześcijan oraz wojsko. Powolnej destrukcji świątyń dokonywała najczęściej okoliczna ludność, odzyskująca ze świątyni okazałe bloki kamienne oraz marmurowe płyty. W interesującym nas okresie nie tylko świątynie pogańskie rozbierano na budulec. Ten sam los przypadł również innym budowlom starożytności: teatrom, gimnazjonom i palestrom, bez których człowiek starożytności nie mógł się obejść.

8. Opuszczone świątynie. Źródła późnoantyczne donoszą również o istnieniu opuszczonych, najczęściej tylko splądrowanych świątyń pogańskich. Do zniszczenia świątyń nie dochodziło przede wszystkim na obszarach na których nie było wielu chrześcijan lub też jeśli świątynie te leżały w miejscach oddalonych od większych skupisk ludzkich lub też ciągów komunikacyjnych. Taka sytuacja sprzyjała pozostawieniu świątyń swojemu losowi. Budowle te były najczęściej tylko plądrowane lub tylko częściowo rozbierane, na przykład poprzez demontaż ozdobnych kolumn lub marmurowych płyt. W takich opuszczonych świątyniach osiedlali się niekiedy pojedynczy mnisi, prowadząc walkę $\mathrm{z}$ „,demonami”"91 lub nawet grupy mnichów ${ }^{92}$. Czasami w opuszczonych świątyniach zatrzymywali się na noc podróżni ${ }^{93}$.

9. Uwagi końcowe. Mając na uwadze powyższe rozważania należałoby zadać jeszcze kilka pytań. Po pierwsze, czy źródła donoszą o jakichkolwiek działaniach pogan mających na celu uchronienie ich świątyń przed atakami chrześcijan? Niektórzy spośród pogańskich intelektualistów, jak Libaniusz czy Temistiusz, przy pomocy argumentacji słownej bezskutecznie próbowali nakłonić władców, aby ci nie tolerowali niszczenia świątyń przez fanatycznych chrześcijan, w tym przede wszystkim mnichów. Natomiast w miastach, w których poganie stanowili większość, nie przyjęto bynajmniej postawy pasywnej wobec podobnych akcji chrześcijan, co potwierdzają chociażby bitwy uliczne pomiędzy poganami a chrześcijanami, do których dochodziło w czasie plądrowania i burzenia świątyń pogańskich przez chrześcijan w Aleksandrii, Gazie czy w syryjskim Aulon. O tym, iż podobnym akcjom często towarzyszyły zamieszki w miastach świadczy również jedno z rozporządzeń cesarskich, w którym stwierdza się, że świątynie pogańskie winny być niszczone bez

${ }^{91}$ Callinicos, Vita Hypatii 43; Apopfhtegmata Patrum Abba Eliasz 7 (265); tamże, (Macedoniusz); Vita s. Danielis Stylitae, ed. A.-J. Festugiere, dz. cyt., 14-15. Por. także D. J. Chitty, The Desert a City: An Introduction to the Study of Egyptian and Palestinian Monasticism under the Christian Empire, Oxford 1966, s. 8, 34, 54-55, 69.

${ }^{92}$ D. J. Chitty, dz. cyt., s. 54-55.

93 Apophtegmata Patrum Abba Anub 1 (138). 
jakichkolwiek rozruchów (sine turba ac tumultu) ${ }^{94}$. Opór ten jednak na dłuższą metę nie mógł przynieść oczekiwanych rezultatów, gdyż przeciwnik - chrześcijaństwo, był silniejszy mając poparcie cesarskiego majestatu, a świątynie pogańskie w myśl nowej polityki religijnej państwa nie miały już racji bytu. Natomiast na tych obszarach Imperium, gdzie poganie stanowili mniejszość, przyjmowali oni raczej postawę pasywną wobec niszczących ich świątynie chrześcijan $^{95}$.

Świątynie położone z dala od skupisk ludzkich można było oszczędzić przed grabieżą opłacając okoliczną ludność, by broniła ją przed atakami chrześcijan, jak to było chociażby w przypadku świątyni Zeusa w Aulon, gdzie, jak stwierdza Sozomen, świątyni tej bronili okoliczni poganie ${ }^{96}$. Czasami odwleczenie realizacji cesarskiego rozporządzenia nakazującego zamknięcie bądź zniszczenie świątyni można było osiągnąć ofiarując łapówkę pieniężną odpowiednim urzędnikom ${ }^{97}$.

W jaki sposób późnoantyczni biskupi postrzegali sens patronowania i nawoływania do destruktywnych akcji względem świątyń? W tych akcjach można dopatrywać się chęci wykazania bezsilności starych bogów w konfrontacji z Bogiem chrześcijan, bogów, którzy nie byli w stanie przeciwdziałać niszczeniu swych miejsc kultu. Takie przypuszczenie wydaje się słuszne, jeśli weźmiemy pod uwagę relacje Rufina $\mathrm{z}$ Akwilei i Teodoreta z Cyru, opisujących zniszczenie przez chrześcijan posągu Serapisa w Aleksandrii w 391 roku $^{98}$.

W jakim stopniu zarządzenia nakazujące zamykanie świątyń czy nawet ich destrukcję mogły przyczynić się do postępu chrystianizacji społeczeństwa oraz jak trwałe były rzekome „nawrócenia”? Prowadzona przez państwo i Kościół polityka zmierzająca do wytępienia pogaństwa, była na tyle skuteczna, na ile autorytet władzy, w tym przede wszystkim rzetelność i lojalność urzędników prowincjonalnych, mógł gwarantować wykonywanie tych nakazów. Choć również na Wschodzie dostrzegano zjawisko nawróceń koniunkturalnych ${ }^{99}$, to jednak skalę tego zjawiska oraz powierzchowność chrystianizacji społeczeństwa późnoantycznego widać na przykładzie prowincji zachodnich. W przypadku słabości strażnika praw, nazbyt powierzchownej chrystianizacji społeczeństwa, w obliczu zagrożenia ze strony barbarzyńców, lokalne społeczności podejmowały próby odnowienia starych kultów. W 451 roku cesarz Walentynian

${ }^{94}$ CTh XVI 10, 16.

95 Por. działalnośc Szenutego z Atripy w Egipcie (J. Leipold, dz. cyt., s. 179-181).

96 Sozomenus, HE VII 15.

97 Por. przykład misji subadiuwy Hilariosa w Gazie w 398/399 roku (Marcus Diaconus, Vita Porphyrii, 27).

98 Rufinus, HE II 23; por. także Thedoretus, HE V 22. Rufin utrzymuje, iż posąg Serapisa został zniszczony w miejscowym teatrze na oczach tysięcy pogan, Teodoret natomiast, iż zniszczenia dokonano jeszcze w świątyni.

99 Libanios, Oratio XXX 28. 
III wydał rozporządzenie zakazujące otwierania od pewnego czasu nieczynnych już świątyń i oddawania czci starym bogom. Z owego rozporządzenia wynika także, iz ludność w obliczu groźby huńskiego najazdu na Italię zaczęła ponownie składać ofiary, palić kadzidła oraz przyozdabiać kwiatami drzwi świątyń ${ }^{100}$. Zamknięcie bądź zburzenie świątyni pogańskiej najczęściej owocowało przyciągnięciem pogan nie tyle do samej idei chrześcijaństwa, co do jego miejsc kultu. Takie stwierdzenie potwierdza relacja Sozomena, według którego poganie w wielu miastach z braku dostępu do własnych świątyń zaczęli z biegiem czasu uczęszczać do kościołów ${ }^{101}$.

Zjawisko występowania chrześcijan przeciw świątyniom było jednym z wielu elementów składających się na proces chrystianizacji Imperium Rzymskiego w późnej starożytności. Akcje skierowane przeciw świątyniom nie były prowadzone systematycznie. W wielu przypadkach w zamkniętych już świątyniach odżywał stary kult, choć sprawowany ukradkiem. Czasami zdarzały się także przypadki funkcjonowania świątyń pogańskich jeszcze w końcu V, a nawet $w$ połowie VI wieku ${ }^{102}$. Nie należy również zapominać, iż proces adoptowania przez Kościół świątyń pogańskich w późnej starożytności zaowocował pozytywnymi skutkami, gdyż w taki to sposób niektóre spośród nich dotrwały do naszych czasów. Poza tym także powtórne wykorzystywanie bądź burzenie świątyń pogańskich w późnej starożytności w pewnym stopniu zmieniło również wygląd i charakter miast antycznych. Opisywane przez nas zjawisko nie było jednak odosobnione. Począwszy od połowy VII wieku na Wschodzie wiele kościołów spotkał podobny los, jaki chrześcijaństwo zgotowało świątyniom pogańskim w IV i V wieku. Wiele z kościołów przejętych przez muzułmanów przebudowano na meczety, wykorzystywano jako budynki gospodarcze lub też na skutek powstałych zniszczeń na skutek trzęsień ziemi rozbierano na budulec ${ }^{103}$.

${ }^{100}$ Codex Iustinianus I 11, 7, ed. P. Krueger, Berolini 1892.

101 Sozomenus, HE VII 20; por. także V. Schultze, Geschichte.., Bd. II, s. 235.

102 Joannes Ephesinus, HE III 36; C. Foss., Ephesus after Antiquity: A Late Antique, Byzantine and Turkish City, London - New York 1979, s. 32; M. Whitby, John of Ephesus and the Pagans: Pagan Survivals in the Sixth Century, w: Paganism in the Later Romam Empire and in Byzantium, ed. by M. Salamon, Cracow 1991, s. 111 i nn.; P. Nautin, La conversion du temple de Philae en Église chrétienne, „Cahiers Archeologique”, 17(1967) 1-43.

103 R. Schick, The Christian Communities of Palestine from Byzantine to Islaamic Rule. A Historical and Archeological Study, Princeton - New Jersey 1995, s. 129 i nn. 


\section{DIE WEITERVERWENDUNG DER HEIDNISCHEN TEMPEL IN DER SPÄTANTIKE \\ (am Beispiel der oströmischen Provinzen)}

\section{Zusammenfassung}

In diesem Beitrag wurde die Weiterverwendung der heidnischen Tempel in der Spätantike in den östlichen Provinzen des Römischen Reiches dargestellt. Die ersten gesetzlichen Massnahmen gegen Tempel wurden durch Konstantin dem Großen ausgegeben. Dann began auch die Zerstörung der heidnischen Heiligtümer. Kaiser Konstantin übte jedoch im Vergleich mit seinen Nachfolgern eine gewisse Zurückhaltung in seiner Politik gegen das Heidentum. Den Aktionen gegen heidnische Heiligtümer begleitete die Einziehung der Tempelgüter. Die Politik der römischen Kaiser gegen Tempel war in verschiedenen Fällen inkonsequent. Trotzt der antiheidnischen Politik der spätantiken Herscher, brannte in vielen Tempel weiterhin das Opferfeuer und es wurden auch weiterhin Opfer dargebracht. Nur für kurze Zeit im 4. Jh. kam es zu einer politisch - religiösen Wende zur Zeit Kaiser Julians. Dieser ordnete Wiederöffnung der gesperten so wie auch den Wiederaufbau der zerstörten Tempel an. Der Höhepunkt der Aktionen gegen Tempel war an der Wende von 4. zum 5. Jh., zur Zeit des Kaisers Thedosius des Großen und seines Sohnes Arkadios.

Viele von der heidnischen Tempel wurden im 4. und 5. Jahrhundert zerstört, unter diesem auch die im ganzen Osten bekannten Tempel (Serapejon in Alexandrien und Marnejon in Gaza). Es gab jedoch auch andere Heiligtümer (z. B. der Tempel von Baal in Heliopolis in Phönizien), die trotzt ihres Ruhmes nicht zerstört wurden. Meist wurden die heidnischen Tempel in die Kirchen umgebaut. Viele dienten nach Umbau aber ganz anderen Zwecken: als Wohnhäuser, Schulen, Wohltätigkeitsanstalten, Tavernen, Speichern, Warenhäuser oder auch als Steinbrüche. Das so gewonnene Baumaterial wurde zur Pflasterung der Straßen so wie auch zur Reparatur der Brücken, Wasserleitungen und Thermen genutzt. 